\title{
Religion, Moral and Modernisation of Urban Society: A Study on the Roles of Religion in Youth Development in Lampung, Republic of Indonesia
}

Suhandi ${ }^{1}$ \&Azhar Jaafar ${ }^{2}$

${ }^{1}$ Universitas Islam Negeri Raden Intan, Indonesia \& ${ }^{2}$ University College of Yayasan Pahang, Malaysia

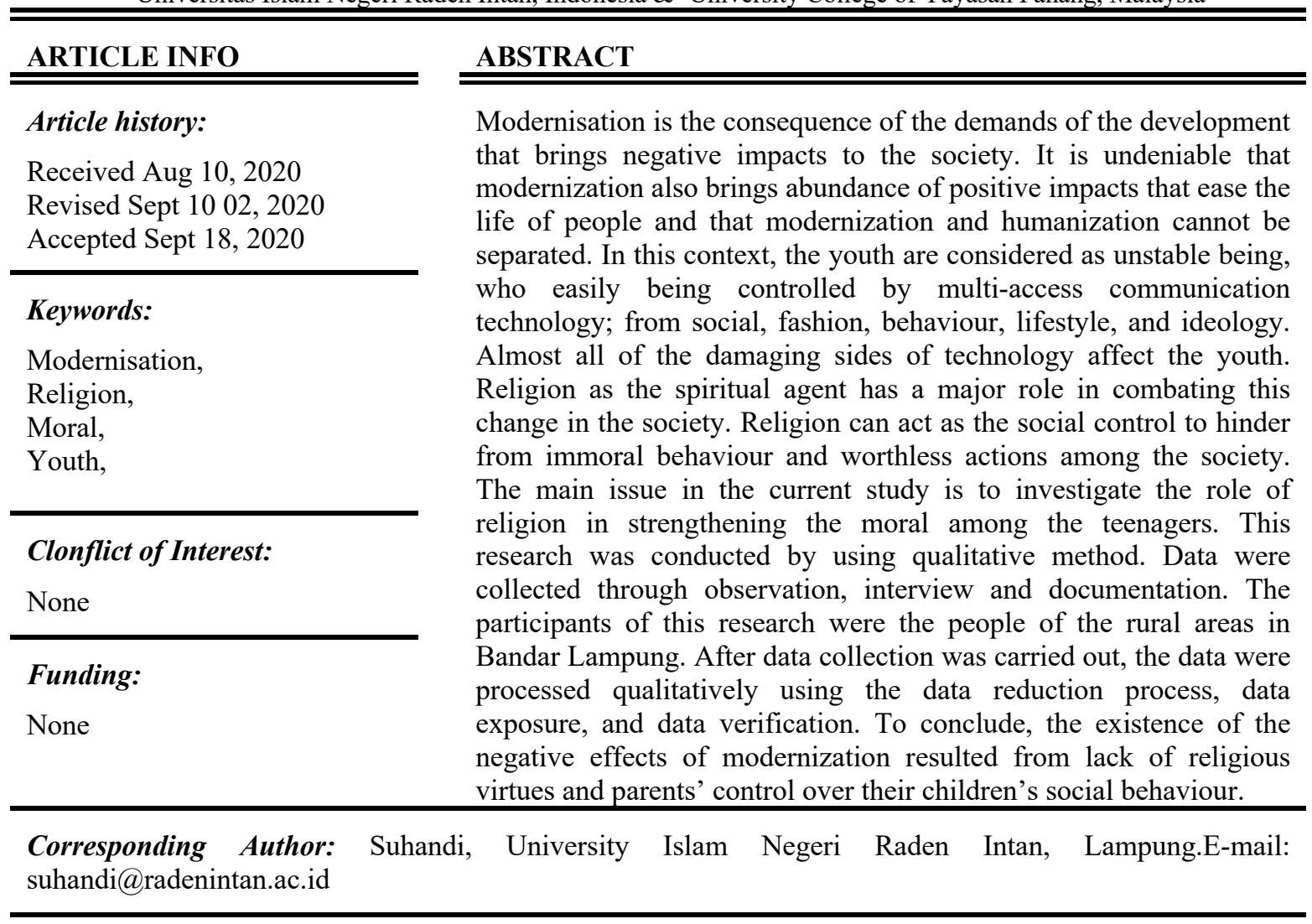

\section{Introduction}

Studies with regard to religion continue to grow and become one of important and well-known studies in academic world. This is because religion is universal, general and comprehensive in nature in any community (Ramli, 2015:139), that modernisation is not a new term and process in human history. According to Fuzie Nurdin, modernisation started in Italy in the 15th Century and spread to most part of the world in the next five centuries. Now, modernisation takes place in every part of this world. The first manifestation of modernisation that can be seen in England in the 18th Century, as known as the industrial revolution in Asian countries, was especially famous in Japan in realising the revolution around one century ago (Fuzie Nurdin, 2014: 29). The growing of information technology among the people is one of the crucial factors in these revolutions. The birth of social media has made people's behaviour patterns experience a shift in both culture, ethics and existing norms (Anang Sugeng Cahyo, 2016:140).

The terms are modern popular or modern time or characteristic of the present or recent time (Abdullah Sulesana, 2013:15). The term modern has always been used in contradiction of traditional. It comes from the Latin word modenus from the words modo and ernus. Modo means way and ernus refers to the existence of the present time. Hence, modernisation means the process towards the present time or modern society 
(Nanang Martono, 2012:80). Furthermore, modernisation is a process of transformation from one change to better or more advanced in any aspects of humanity. Simply put, modernization is a process of change from traditional to more advanced new ways, which are intended to improve the welfare of society (Ellya Rossana, 2011:33). However, it is quite certain that modernisation causes disorganised in society. Moreover, modernisation is beginning to involve the values and norms of society. Too fast a process could only lead to continuous disorganization because the community does not have time to reorganize (Soejono Soekanto, 2012:301). Even in the 21st century, which is known as the era of transparency or the era of cross-border (globalization) which is marked by advances in science and technology, has had an impact on changes in social behaviour (Asrul Muslim, 2013:488).

Generally, the people of rural areas of Lampung city are still traditional. However, with the development of technology in various fields and the increasingly advanced developments of the times, inevitably people outside Bandar Lampung must also adapt to these changes and developments. So much so that many negative effects arise and raise new questions for the development of society; especially those related to attitudes and behaviours. Those who are deeply affected by this situation are none other than the youth. Many scholars define adolescence, such as DeBrun defines adolescence as a period of growth between childhood and adulthood (Khamim Zarkasih Putro, 2017:25). Psychologically, adolescence is seen as a period of transition; this gives them time to try different lifestyles and determine the behaviour patterns, values and traits that best suit them. During this age emotional symptoms and mental distress arise, so that their behaviour sometimes seems distorted (Abdullah Idi \& Jamali Sahrodi, 2017:3).

In addition, adolescence is a time when there is a period of change in emotions, changes in the body, interest and change in the values embraced, and the desire for freedom.

It is a period of seeking self-identity, which is sought in the form of an attempt to explain who he is and what his influence is in society (Elizabeth B. Hurlock, 2003: 207-2011). The changes happen quite rapidly that sometimes it could be unnoticeable (Jose RL. Batubara \& Sari Pedriatri, 2010:21). This situation makes adolescents very vulnerable to do or imitate anything that can be accessed, without considering whether there are good or bad, and advantages or vice versa. Conger and Erikson call adolescence a very critical time that may be the best of time and the worst of time (Sofa Muthohar, 2013:324).

This phenomenon demands religions to play their parts as guidance and dynamic social controller. In any community, religion is considered as the main pillar in spiritual life (Rizal Mubit, 2016:164). Guidance and guidance through religious education has a huge impact on a person as a tool to control all forms of attitudes and behaviors in daily life. This means that the religious values he acquires can be part of his personality that will automatically control his behaviour. From a psychological perspective, Sigmund Freud also said that religion greatly influences individual behavior. Religion is not only in the realm of the mind of rational reason, but also in the realm of one's subconscious (inner) (Aulia Aziza, 2016:2). Thus, religion has a big role in fortifying adolescent behavior in order to avoid negative actions that can harm adolescents themselves. Sociologically, it is undeniable that religion is not only seen as something that is doctrinal-ideological in nature which is abstract, but also appears in material forms, namely in everyday life (Moch. Fakhruroji, 2015:193). So much so that there is an interdependence relationship between religion and society, where the two influence each other (Mahli Zainudin Tago dan Shonhaji, 2013:82-83), or often referred to as the dialectical process of religion and culture. According to the anthropologists, this phenomenon is considered as a process of externalization, objectivation and internalization (Roibin, 2010:2).

In this research, the rural areas of Bandar Lampung that will be the focus of the study are Jati Agung subdistrict, Panjang subdistrict, Natar subdistrict, Kemiling subdistrict and Padang Cermin subdistrict. Geographically, these are the rural areas in Bandar Lampung and has a fairly dense population and a very heterogeneous life in terms of religion, ethnicity, culture, and socioeconomic. Strategically these areas are quite close to the city, and smooth access to urban, because it is supported by adequate means of transportation and roads, especially the world of technology that indirectly plays a role in spreading lifestyle through mass media such as TV and the Internet. Easy access to information has its pros and cons. Indirectly, the development in the city affects these rural areas.

Puberty is important to review, as each individual goes through adolescence in his or her life span. The youth should be able to develop all the potential that is in him so that he can go through his development without stress and full of anxiety (Miftahul Jannah, 2016:243). During this period, social development is vital where they are urged to fit in effectively (Carmia Diahloka, 2012:26). Furthermore, according to Soerjono Soekanto, the existing norms in society have different binding powers. Some are weak while others are very strong. To be able to distinguish the strength of binding these norms sociologically known by 4 meanings, 
namely: usage, folkways, mores, and customs (Soejono Soekamto, 2012:175). Youth unpreparedness in fortifying themselves with religious values results in an inevitable negative impression; such as meskirtok, alcohol consumption, drug abuse, teenage fights, student brawls, and motorbike gangs and others. Therefore it is necessary to do further studies, to see the extent of the role of religion in fortifying the morals of adolescents.

From the overview above, there are two problem areas formulated in this research, which are;

Why does modernization have a strong influence on the morale of adolescents in the rural areas of Bandar Lampung?

How the role of religion in fortifying the morals of adolescents from the negative influences of modernization?

\section{Method}

This research was conducted on the rural community of Bandar Lampung with a large population of young $p$ eople living in the region and a fairly large area covering five subdistricts, namely (1) Jati Agung subdistrict, (2) Panjang subdistrict, (3) Natar subdistrict, (4) Kemiling subdistrict and (5) Padang Cermin subdistrict. Thi $\mathrm{s}$ is a field research, which studies the lifestyle of the society. The main data (primary data) that must be colle cted is data obtained from the results of observations on the phenomena of public life, interviews with some $\mathrm{i}$ nformants in accordance with the needs and documents. While all literature related to this investigation, whet her from books, papers, journals, research results and others are only as complement (secondary data) (Choli d Narbuko dan Abu Achmadi, 2010: 46). So this research will be done on the activities of adolescents living i $\mathrm{n}$ rural areas by looking at the extent to which they are influenced by modernization, which has a bearing on moral degradation.

The approach used in this study is a sociological approach, which is an approach used in observing society, w hich is very much related to social groups, researching and understanding the life of the group scientifically ( Soejono Soekanto, 2012: 95). The sociological approach examines religious phenomena that accumulate in $\mathrm{h}$ uman behavior in relation to social and cultural structures that are shared, shared and supported (Soejono Soe kanto, 2012: 95). Researchers use a sociological approach because this study emphasizes adolescent moral be havior patterns. In extracting information, three methods are used; namely observation methods, interviews a nd documentation.

Once all the required data has been collected and data validation has been done, the next stage is data analysi $\mathrm{s}$, which is the process of compiling data so that it can be interpreted. Organizing data means categorizing it $\mathrm{i}$ nto patterns, themes, or categories of interpretation; that is, giving meaning to analysis, explaining patterns or categories and finding relationships between various concepts (Dadang Kahmad, 2002:133). In qualitative res earch, researchers are the instrument of analysis since the beginning of data collection. Thus, in qualitative re search the term Key Instrument is known; which means researchers act as instruments as well as data collecto rs, in addition to other instruments that can be used. Therefore, the presence of researchers in the field is abso lutely necessary (compulsory) (Lexy J. Moleong, 2014: 8).

According to Miles \& Huberman, every data analysis process includes three sub-processes, namely data redu ction, data display, and data verification (Moh. Soehada, 2012:129). In qualitative research, the data analysis process essentially begins before data collection is carried out, that is, the investigator plans and designs the $\mathrm{i}$ nvestigation, and takes place at the time of collection and after the final process of all data collection is carrie $\mathrm{d}$ out. So, data analysis in qualitative research is done at any time during the research process. And the three $\mathrm{s}$ ub-processes of analysis are not carried out sequentially or in alternating stages, but the process will run in a circular and interactive manner during the data collection process which has started from the initial survey to the end of the process of collecting all the required data.

Conclusions will be drawn using inductive methods; that is, analyzes that are specific to all the information th at can be collected, both the phenomena that arise from the field and the information obtained from the infor mants through interviews; nor the data obtained from the documents are inferred into general conclusions.

\section{Results and Discussion}

The moral of the youth in general is heavily influenced by the modernity process which is dominated by the sophistication of information technology development, tends to display the phenomenon of moral degradation. Because for the community, especially among teenagers, social media has become an addiction that makes its users have no day goes by without logging in to social media (Wilga Secsio Ratsja Putri, R. Nunung Nurwati, \& Meilanny Budiarti S., 2012:47).

Youth and Alcohol: The modernity of a region makes the mindset of adolescents also change, unlike most teenagers in the past, where everything was told to their parents. Today's teenagers often share stories with their peers who are considered more understanding. They consider their parents are old and out of date. However, the negative impression is that when a friend of this teenager deviates, the teenager will somehow 
influence by the act and thinking of doing the same. They share their problems with friends and get into habit of drinking alcohol. There are several drinking teenagers in the area outside Bandar Lampung.

Youth and Pornography: With the rapid development of communication technology and mass media, it is easy for teenagers to access anything through communication media (internet). This condition makes it easier for them (teenagers) to access whatever they want, including seeing what they should not see, such as pornographic videos that are freely circulating on YouTube.

Youth and Indecent Clothes: On July 10, 2019, during observations, researcher found two teenage girls coming home from school wearing gray short skirts above the knees. The school rules (Permendikbut No.45/2014) indicate that the school uniform for female students must be $5 \mathrm{~cm}$ below the knees. This is due to the large number of soap operas on TV that provide bad examples to adolescents, like wearing short skirts to school.

Youth and TikTok: Researcher also found three teenage, still in their school uniforms, was doing TikTok video in a shop and do not even care of people passing by including their teachers. Conditions like this after the interview they were much influenced by social friends and television shows that mostly show teenagers who have a free lifestyle. Indirectly, what they watch on television teach them negative things.

Youth and Illegal Racing: Television shows bring out negative things to the teenagers so parents should monitor their children. Physically, teenagers seem matured yet sometimes they cannot tell apart the good from the bad. This is the more reason for parents to monitor what their children watch on TV. There are many teenagers who imitate the soap operas on television that teach them speeding, and as if it is legal.

There are roles that have been played by religion (religious figures, religious organizations and institutions, educational institutions), but the percentage is still not very significant as a control and filter for the lives of adolescents.

Outside Bandar Lampung city, religious leaders have appeared in every mosque who have played their role as religious experts to provide advice through religious forums such as Islamic major celebrations at various mosques and mushallas annually so the preachers able to enlighten the society in general. Here, Islamic syi'ar has been carried out by activists and religious and community leaders through continously commemorating Islamic holidays.

Religious organizations and institutions located outside Bandar Lampung city have sprung up to contribute and care for the development of society. There is the Nahdhatul 'Ulama (NU) organization with its traditional approach (community tradition), at the sub-district, district and city levels, the Muhammadiyah organization with reforms in its education, the LDII organization with its very exclusive doctrinal dogma which teaches the education of aqidah and community morals to become Muslim obey the teachings of Islam. Tarkat activist groups who seek to build people from a spiritual side by prioritizing purity of heart and soul so that they become Muslims who are always close to Allah SWT., such as Pesantren Arafah in Natar, Jama'ah Thalabul 'Ilmi Sumur Putri Telukbetung Barat. And many more religious organizations have emerged to strive to provide guidance and solutions to the problems faced by Muslims and society in general.

The educational institutions around the rural areas of Bandar Lampung have also contributed to enlighten the life of the nation, especially for the community around Bandar Lampung. This is from the emergence of new educational institutions and developing dynamically. Whether based on general education, or religious-based education, such as SDIT Baitul Jannah, SDIT Muhammadiyah, SDIT Insan Kamil, SMPIT Mujtma 'alIslami, TK and SDIT As-Salam, SDIT and SMPIT Permata Bunda, Tahfidz Al-Hidayah Islamic Boarding School, and tahfidz houses have sprung up around the city of Bandar Lampung. The development of educational institutions with a strong Islamic base indicates that religion has shown its existence as an educator and mentor of the mental and spiritual community, as a bulwark against the swift influence of modernization in people's lives. And conceptually Islamic education guides students in their own development, both physically and spiritually towards the formation of the main personality in students later based on Islamic laws (Nur Hidayat, 2015:144).

\subsection{Discussion}

Modernizations; Modernization is a complete process that encompasses everything, so that it cannot be learned in any scientific field only, then various fields of expertise of people will tend to limit themselves to only one symptom, which should be viewed as an aspect of the whole process. Another possibility to define the process of modernization of society is by using indicators. That is, we choose one process, which changes along with the course of modernization of society. If the process of modernization is seen as an inevitable 
one, involving all existing countries, then the question arises, does modernization also mean westernization (JW. Schoorl, 1980:32).

Modern society needs to be achieved. The forms, for example, are a more egalitarian society (more equal in taste), an elite society (more concerned with the existence of the elite), more concerned with the individual, or preferring collective behavior patterns and so on. Max Weber is a German sociologist who is considered as the father of modern sociology with his modernization theory of protestant ethics which is the role of religion that influences individual behavior. Where the values of living in society can be directed to a positive attitude towards economic growth, then the process of development in society can be implemented.

As for these forms of modernization, among others: Change of Mindset, mindset is a way of thinking called mind-set is a belief or way of thinking that affects a person's behavior and nature that ultimately determines the level of success of his life. Changes in the mindset of the indigenous people, then the post-independence period as the foundation for the formation of a new, independent society, and finally its development which is the parameter of success (Agus Sachari, 2007: 21).

Behavior changes; the formation of behavior can occur due to the process of interaction with the environment. Behavior that applies to individuals or organisms does not arise by itself. According to Robert Kwick, behavior is an organism that can be observed and can even be studied. In its development, a person's behavior can change according to the things that allow the change to occur. In his development in life, human behavior is influenced by several internal and external factors that allow him to experience changes (Sani Parwasih www.saniparwasih.blogspot.com 28 September 2018).

Technology changes; Technological development is very necessary. Every innovation is created to provide positive benefits for human life. Providing many facilities and new ways to do human activities specifically in the field of technology makes society already enjoy the many benefits brought by the innovations that have been produced in the last decade. But human beings cannot deceive themselves by the fact that technology also has various negative effects for human beings themselves. On the one hand, the amazing development of the world of technology has brought tremendous benefits to the advancement of human civilization. There is no doubt that technological advances have been recognized and felt to provide a lot of convenience and comfort for human life, but apart from positive influences and impressions, the rapid advancement of technology also gives a negative impression. The positive effect of technological development is, we get the most accurate and up-to-date information on any part of the earth through the internet, we can communicate with friends and family very far just by using a mobile phone, and get the convenience of bank service (Akbar,: https://akbarsaiful.wordpress.com 28 September 2018). The negative impression of technological development is the misuse of information and communication services by certain people for purposes that are detrimental to others. In the socio-cultural field, technological developments also give positive and negative impressions. The positive impression is that the increasing self-confidence of economic progress in Asian countries has given birth to an interesting phenomenon. This progress will increase self-confidence and selfdefense as a nation will be stronger. Pressure and competition, sharp competition in various aspects of life as a consequence of globalization, will give birth to a generation that is disciplined and hardworking (Akbar,: https://akbarsaiful.wordpress.com, 28 September 2018). The negative impact of technological developments in the socio-cultural aspects is the moral decline among the people, especially among adolescents and students. The advancement of economic life, which overemphasizes the fulfillment of various material desires, has caused some people to become materially rich but spiritually poor. Juvenile delinquency and deviant behavior are increasing. The weak authority of existing traditions in society such as gotong royong and tolong menolong has weakened the forces that play an important role in creating social unity. The changing patterns of human interaction. The presence of computers in most upper-middle-class households has changed the pattern of family interaction. Computer-connected phones have opened up opportunities for anyone to connect with the outside world, as a result of which humans no longer interact directly.

Moral Degradation; Etymologically, the term moral comes from the Latin "mores" which means customs, habits, ways of life (Sahmiar Pulung, 2011:10). Meanwhile, in moral terminology, moral is a teaching about the good and bad of an act and behavior (Zuldafrial, 2014:30). And in fact the symptoms of moral degradation are increasingly evident in this era of globalization, where many young people do things that deviate from existing norms (Yunisca Nurmalisa Muhammad Mona Adha, 2016:65). The decline in moral values and character of adolescents can be seen from several incidents and behaviors of criminal acts that are increasingly widespread in various types, forms and patterns that are often found in mass and electronic media (Audah Mannan, 2017:60). Symptoms that indicate a moral decline in young people in some respects namely; 
Mischief; For example, stubbornness, do not want to obey their parents and teachers, absent from school, neglecting studies, getting into fights, obscene language, indecent clothing and and so on.

Mischief that disturbs the peace and safety of others.

Sexual behaviour; The misdeeds or moral damages of children who upset their own parents and also some who disturbed themselves. Many parents are worried about their children. Sexual harassment among youth includes same sex (homosexual) (Zakiah Darajat, 1984:10)

Among other factors;

Lack of embedded religious spirit in each person in society; Religious beliefs based on a genuine and healthy understanding of the religion they profess, then accompanied by the implementation of these teachings are the strongest moral fortresses. When religion has become an integral part of a person's life then that belief is the one that oversees all actions, words and even feelings

Less stable state of society, both socially and politically; The second factor that also influences morale is the lack of stability of the situation for economic, social and political. Shaking or instability of the environment that surrounds a person causes anxiety as a result of not being able to achieve a sense of security and peace in life.

Improper implementation of moral education at home, school or community; The third factor is the lack of good moral education, in the household, morals and society. Moral development should be carried out from an early age, according to his ability and age. Because every child is born, does not yet understand what is right and what is wrong, and does not know the boundaries and moral conditions that apply in his environment. Without being accustomed to instilling good qualities in moral growth, children will be raised without knowing that moral. This is where the roles of parents, teachers and the environment are very important.

Poor household atmosphere; The fourth factor that is also visible in today's society is that the harmony of life in a household is not guaranteed there is no mutual understanding, mutual acceptance, mutual respect, mutual love between husband and wife.

There are many writings, pictures, broadcasts, arts that do not pay attention to the basics and moral demands; The fifth factor that has recently become less of our attention is, the writings, readings, paintings, broadcasts, arts and games that seem to encourage young people to follow. Morally and mentally less attention is paid, the works of art are merely expressions of desires and needs that cannot be met. Then it is described very realistically, so that everything that is stored in the hearts of teenagers is revealed and realistically seen in the story, painting or game. This encourages young people to have a moral breakdown.

Lack of guidance to fill leisure time in a good and healthy way that leads to moral development. Young age is the age of daydreaming, daydreaming things away. If they are left without guidance in filling their time, then many fantasies and unhealthy behaviors will arise from them.

Lack of guidance and counseling centers for children and youth that will accommodate and channel children in a healthy mental state. With little or no return for restless children, a less pleasant behaviour will emerge.

\section{Conclusion}

Some of the conclusions in the discussion of this study are as follows;

Modernization which is strengthened by the current of globalization greatly affects the moral degradation of adolescents, because the development of information technology is inevitable and has spread widely to all generations of adolescents in areas outside Bandar Lampung.

Meanwhile, religion has actually played a role as a social control and spiritual agent to provide mental defense to adolescents.

However, with all the limitations and size of the area, this role is not significant enough to be felt by all teenagers outside Bandar Lampung.

\section{References}

Akbar, "Kesan Dan Perubahan Perkembangan Teknologi” (On-line), Tersedia di: https://akbarsaiful.wordpress.com (28 September 2018)

Darajat, Zakiah, Membawa Nilai-nilai Moral di Indonesia, jakarta: Bulan Bintang, 1984. 
, Dinamika Sosiologi Indonesia: Agama dan Pendidikan dalam Perubahan Sosial, Yogyakarta: LKIS Pelangi Aksara, 2015. , Ilmu Jiwa Agama, Jakarta: Bulan Bintang, 1970.

Elizabeth B. Hurlock, Psikologi Perkembangan, (Jakarta: Erlangga,2003.

Kahmad, Dadang, Model penyelidikan Agama dan Dinamika Sosial, (Jakarta: PT. Raja Grafindo Persada, 2002).

Martono, Nanang, Sosiologi Perubahan Sosial: Persfektif Klasik, Moden, Posmoden, dan Poskolonial, Jakarta: Rajawali Pers, 2012.

Moleong Lexy J., Metode Penyelidikan Kualitatif, (Bandung: Remaja Rosda Karya, 2014).

Narbuk, Cholid dan Abu Achmadi, Metodologi Penyelidikan, (Jakarta: PT. Bumi Aksara, 2010).

Nurdin, Fauzi, Sosiologi Pembangunan, Jogyakarta: Panta Rhei Books, 2014.

Sachari, Agus, Budaya Visual Indonesia, Jakarta: Erlangga, 2007

Sani Parwasih, "Teori Perubahan Prilaku" (On-line), Tersedia di: www.saniparwasih.blogspot.com (28 September 2018)

Soehada, Moh., Metode Penyelidikan Sosial Kulaitatif Untuk Studi Agama, (Yogyakarta: SUKA-Press UIN Sunaan Kalijaga, 2012).

Soekanto, Soerjono, Sosiologi Suatu Pengantara, Jakarta: Rajawali Pers, 2012.

Abdullah Idi \& Jamali Sahrodi, Moralitas Sosial dan Peranan Pendidikan Agama, INTIZAR, Vol. 23, No.1, 2017.

Abdullah Sulesana, Studi Tentang Modernisme Indonesia, Jurnal Wawasan Keislaman, Vol. 8 No. 2, 2013.

Anang Sugeng Cahyo, Pengaruh media sosial terhadap perubahan sosial masyarakat di Indonesia, Vol. 9, No. $1,2016$.

Asrul Muslim, Interaksi Sosial Dalam Masyarakat Multi Etnis, Jurnal Diskursus Islam, Vol. 1, No. 3, 2013.

Audah Mannan, Pebinaan Moral Dalam Membentuk Karalter Remaja (Studi Kasus Remaja Peminum Tuak di Kelurahan Suli Kecamatan Suli Kabupaten Luwu) Jurnal Aqidah Ta: Jurnal Ilmu Aqidah, Vol. III, No. 1, 2017.

Carmia Diahloka, Pengaruh Sinetron Televisi Dan Film Terhadap Perkembangan Moral Remaja, Jurnal Reformasi, Vol. 2, No. 1, 2012.

Ellya Rosana, Modenisasi dan Perubahan Sosial, Jurnal Tapis: Teropong Aspirasi Politik Islam, Vol.7, No.1, 2011.

Joko Tri Haryanto, Relasi Agama Dan Budaya Dalam Hubungan Intern Umat Islam, Jurnal SMaRT: Studi Masyarakat, Religi, dan Tradisi, Vol. 1, No.1, 2015.

Jose RL Batubara., Adolescent Development (Perkembangan Remaja) Sari Pediatri, Vol. 12, No. 1, Juni 2010.

Ramli, Jurnal Pendidikan Ilmu-Ilmu Sosial, Agama dan Kehidupan Manusia, Vol.7 No.2. 2015.

Khamim Zarkasih Putro, Memahami Ciri dan Tugas Perkembangan Masa Remaja, APLIKASIA: Jurnal Aplikasi Ilmu-ilmu Agama ISSN 1411-8777 Volume 17, Nomor 1, 2017 | Page: 25-32

Komariah, Kokom St., Model Pendidikan Nilai Moral Bagi Para Remaja Menurut Perspektif Islam, Ta'lim: Jurnal Pendidikan Agama Islam, Vol. 9, No.1, 2011.

Mahli Zainuddin dan Shonhaji, Agama Dan Intgrasi Sosial Dalam Pemikiran Cliffeord Geertz, KALAM: Jurnal Studi Agama dan Pemikiran, Vol. 7, No.1, 2013.

Mahli Zainudin Tago, Modenisasi Pesantren: Pergeseran Tradisi Dan Pudarnya Kyai, Jurnal Penelitian Pendidikan Agama dan Keagamaan, Vol.3, No.2,.2005.

Masykuri Abdillah, Hubungan Agama Dan Negara Dalam Konteks Modenisasi Politik Di Era Reformasi, AlAhkam: Jurnal Ilmu Syariah, Vol.XII, No.2, 2013.

Miftahul Jannah, Remaja Dan Tugas-Tugas Perkembangannya Dalam Islam, Jurnal Psikoislamedia Volume 1, Nomor 1, April 2016 
Moch. Fakhruroji, Privasi Agama: Globalisasi dan Komodifikasi Agama, Jurnal Pendidikan dan Ilmu-Ilmu Sosial, 2015.

Nur Hidayat, Peran Dan Tantangan Pendidikan Agama Islam Di Era Global, Jurnal eL-Tarbawi: Jurnal Pendidikan Islam, Vol. VII, No.2, 2015.

Perkembangan Nilai, Moral Dan Sikap Remaja, Zuldafrial, Al-Hikmah: Jurnal Dakwah, Vol. 8, No.2, 2014.

R. Roibin, Agama Dan Budaya-Relasi Konfrntatif Atau Kompromistik, Jurnal Jurisdictie: Jurnal Hukum dan Sysari'ah, Vol.1, No.1, 2010.

Relasi Agama dan Budaya, Aulia Aziza, ALHADHARAH: Jurnal Ilmu Dakwah, Vol. 15, No. 3, 2016.

Rizal Mubit, Peran Agama Dalam Multikulturaliemae Masyarakat Indonesia, Epistemé: Jurnal Pengembangan Ilmu Keislaman, Vol. 11, No. 1, Juni 2016.

S. Muthohar, Antisipasi Degradasi Moral di Era Global, Nadwa: Jurnal Pendidikan Islam, Vol.7, No. 2, 2013

S. Sahmiar Pulung, Membangun moralitas melalui pendidikan agama, Al-Hikmah: Jurnal Agama Dan Ilmu Pengetahuan, Vol. 8, No. 1, 2011.

Sholeh Suiadi, Islam dan Modenisasi, Islamuna, Vol. 1 no.1, 2914.

Wilga Secsio Ratsja Putri, R. Nunung Nurwati, \& Meilanny Budiarti S., Pengaruh Media Sosial Terhadap Perilaku Remaja, PROSIDING KS: RISET \& PKM VOLUME: 3 NOMOR: 1, 2012.

Yunisca Nurmalisa dan Muhammad Mona Adha, Peran Lembaga Sosilal Terhadap Pembinaan Moral Remaja Di Sekolah Menengah Atas, Jurnal Ilmiah Pendidikan Pancasila dan Kewarganegaraan, Vol. 1, Nomor 1, Juni 2016. 